\title{
A Study on Water Quality Assessment of Özen Spring near Suşehri in Sivas, Turkey
}

\author{
Seher Dirican \\ Cumhuriyet University, Suşehri Timur Karabal Vocational Training School, Department of Fisheries, \\ TR-58600 Suşehri, Sivas, Turkey \\ sdirican@cumhuriyet.edu.tr
}

\begin{abstract}
This study describes the water quality assessment of Özen Spring in the Central Anatolia of Turkey. The mean values of overall water quality parameters results have been observed as $\mathrm{pH}$ (7.48), conductivity $(114.7 \mu \mathrm{S} / \mathrm{cm})$, turbidity (6.56 NTU), dissolved oxygen $(9.15 \mathrm{mg} / \mathrm{L})$, oxygen saturation $(95.31 \%)$, biochemical oxygen demand $(1.60 \mathrm{mg} / \mathrm{L})$, nitrate $(2.93 \mathrm{mg} / \mathrm{L})$, nitrite $(0.03 \mathrm{mg} / \mathrm{L})$, orto-phosphate $(0.14 \mathrm{mg} / \mathrm{L})$, sulfate $(3.35$ $\mathrm{mg} / \mathrm{L})$ and chloride $(8.31 \mathrm{mg} / \mathrm{L})$ in Özen Spring. The obtained results were compared in terms of national limit values and international and standart values.
\end{abstract}

Keywords: Özen Spring, Physicochemical parameters, Water Quality, Turkey.

\section{INTRODUCTION}

Water is an essential component for life on Earth. It can occur as surface water in lakes, rain and stream as well as ground water in wells, boreholes and springs. In the total, there is 1400 million billion litre of water, but most of these water is not used for drinking purpose, because $97 \%$ is a sea water and only $3 \%$ is fresh water, out of which $2 \%$ is glacier, only $1 \%$ water is available for portable use where as more water go for irrigation than to drinking sanitation and all other uses (WHO, 2004). Water quality studies is very important to protect the aquatic ecosystems. To date, the water quality of Özen Spring has not been directly studied. The aim of this study was to assessment the water quality of Özen Spring by physicochemical parameters.

\section{MATERIALS AND METHODS}

\subsection{Study Area}

Özen Spring is located in the Yeşilırmak River basin of the Central Anatolian region of Turkey. The minimum flow rate of Özen Spring is $90 \mathrm{lt} / \mathrm{s}$ in summer months. Average height of Özen Spring is about 1500 meters. Özen Spring is a major source of water for drinking and agricultural uses. Özen Spring is located to the east of the Suşehri. It is about $7 \mathrm{~km}$ far from Suşehri district, and approximately $147 \mathrm{~km}$ far from Sivas province centre. The majority of Sivas province shares the climate of terrestrial in which the summer seasons are hot and dry while winter seasons are harsh, cold and snowy (Dirican and Çilek 2014).

\subsection{Sampling and Data Comparisons}

Thise study was performed by using the information about assessment of water quality of Özen Spring from Suşehri Municipality. In this regard, the water quality parameters such as the $\mathrm{pH}$, conductivity, turbidity, dissolved oxygen, oxygen saturation, biochemical oxygen demand $\left(\mathrm{BOD}_{5}\right)$, nitrate, nitrite, orto-phosphate, sulfate and chloride were measured in July 2009 and May 2011. The water samples were collected from Özen Spring. Two and five litter polyethylene bottles were used to determine the physicochemical characteristics of the water. The samples were then stored at $4{ }^{\circ} \mathrm{C}$ until analysis. All samples were analyzed within 24 hours after collection.

The results were evaluated against water quality standards laid by World Health Organization, WHO (2011); Turkish Water Pollution Control Regulation, TWPCR (2008); European Communities Drinking Water Directive 98/83/EC, ECDWD (1998); Turkish Waters Regulation for Human 
Consumption, TWRHC (2005) and United States Environmental Protection Agency National Primary Drinking Water Regulations, USEPA (2009).

\section{RESULTS AND DiSCUSSION}

The basic statistics for all of the water quality parameters measured during the study period are summarized in Table 1. The values of $\mathrm{pH}$ was ranged between 7.45 and 7.50 in Özen Spring. According to the values of $\mathrm{pH}$ was found to be fairly alkaline in Özen Spring. According to the USEPA (1980), accepted water quality criteria indicate a $\mathrm{pH}$ of less than 6.5 units may be harmful to many species of fish. Therefore, the $\mathrm{pH}$ range of 6.5 to 9.0 units would be suitable for the protection of aquatic habitats. According to the USEPA (1980), the mean values of pH were normal in Özen Spring. The obtained $\mathrm{pH}$ values were within the range $(6.5-8.5)$ to permit all natural processes of aquatic life (USEPA, 2009). The pH values fall within the (>6.5 to <9.5) ECDWD (1998), the (>6.5 to $<9.5)$ TWRHC (2005) and the (6.5 to 8.5) WHO (2011) the permissible limits for drinking water.

Table 1. Result of water quality parameters in Özen Spring.

\begin{tabular}{|c|c|c|c|c|c|c|}
\hline Parameters & Units & Analysis Method & Minimum & Maximum & Mean & \pm SD \\
\hline $\mathrm{pH}$ & - & TS3263ISO10523 & 7.45 & 7.50 & 7.48 & 0.04 \\
\hline Conductivity & $\mu \mathrm{S} / \mathrm{cm}$ & TS9748EN2788 & 78.4 & 114.7 & 96.55 & 25.67 \\
\hline Turbidity & NTU & Türbidimetrik & 2.60 & 6.56 & 4.58 & 2.80 \\
\hline Dissolved Oxygen & $\mathrm{mg} / \mathrm{L}$ & TS5677EN 25814 & 8.57 & 9.80 & 9.15 & 0.87 \\
\hline Oxygen Saturation & $(\%)$ & TS5677EN25814 & 78.62 & 112 & 95.31 & 23.60 \\
\hline $\mathrm{BOD}_{5}$ & $\mathrm{mg} / \mathrm{L}$ & Respirometrik & 1.30 & 1.90 & 1.60 & 0.42 \\
\hline Nitrate & $\mathrm{mg} / \mathrm{L}$ & Fotometrik & 2.00 & 3.85 & 2.93 & 1.31 \\
\hline Nitrite & $\mathrm{mg} / \mathrm{L}$ & Nanocolor 200D & 0.00 & 0.05 & 0.03 & 0.04 \\
\hline Orto-Phosphate & $\mathrm{mg} / \mathrm{L}$ & SM4500P-D & 0.08 & 0.20 & 0.14 & 0.09 \\
\hline Sulfate & $\mathrm{mg} / \mathrm{L}$ & SM4500SO ${ }_{4}$-E & 1.19 & 5.50 & 3.35 & 3.05 \\
\hline Chloride & $\mathrm{mg} / \mathrm{L}$ & SM4500Cl-b & 7.01 & 9.60 & 8.31 & 1.83 \\
\hline
\end{tabular}

The conductivity has a mean of $96.55 \mu \mathrm{S} / \mathrm{cm}, 20^{\circ} \mathrm{C}$ and shows ranges from 78.4 to $114.7 \mu \mathrm{S} / \mathrm{cm}, 20$ ${ }^{\circ} \mathrm{C}$ in Özen Spring. The low levels of conductivity obtained for Özen Spring are an indicator of low salt content. According to the TWPCR (2008) if conductivity, is below $<400 \mu \mathrm{S} / \mathrm{cm}$, the water is class-I; if it is $1000 \mu \mathrm{S} / \mathrm{cm}$, the water is class-II; if it is $3000 \mu \mathrm{S} / \mathrm{cm}$, the water is class-III and if conductivity is $>3000 \mu \mathrm{S} / \mathrm{cm}$, the water is class-IV. The maximum conductivity value in Özen Spring has been found to be $114.7 \mu \mathrm{S} / \mathrm{cm}$, and it is class-I according to the TWPCR (2008) in terms of conductivity. It is obvious that Özen Spring has a high water quality standard or I. class. Thus, it can be said that Özen Spring water can be used not only for drinking purpose by disinfecting it, but also for recreational purposes, rainbow trout culture, animal production and other purposes.

The concentration of dissolved oxygen was between 8.57 to $9.80 \mathrm{mg} / \mathrm{L}$ in Özen Spring. In freshwater ecosystems, the minimum dissolved oxygen may not be less than $5.0 \mathrm{mg} / \mathrm{l}$ for aquatic life (Egemen, 2011). The value of dissolved oxygen was good in Özen Spring for aquatic life. According to the TWPCR (2008) if dissolved oxygen is $>8 \mathrm{~m} / \mathrm{L}$, the water is class-I; if it is $6 \mathrm{mg} / \mathrm{L}$, the water is classII; if it is $3 \mathrm{mg} / \mathrm{L}$, the water is class-III and if dissolved oxygen is $<3 \mathrm{mg} / \mathrm{L}$, the water is class-IV. According to those limits, in Özen Spring could be categorized as class-I. Oxygen saturation in water samples has a mean of $95.31 \%$ and shows ranges between 78.62 and $112 \%$ in Özen Spring. According to the TWPCR (2008) if oxygen saturation is $90 \%$, the water is class-I; if it is $70 \%$, the water is class-II; if it is $40 \%$, the water is class-III and if oxygen saturation is $<40 \%$, the water is class-IV. According to those limits, in Özen Spring could be categorized as class-I. The biochemical oxygen demand $\left(\mathrm{BOD}_{5}\right)$ in water samples has a mean of $1.60 \mathrm{mg} / \mathrm{L}$ and shows ranges between 1.30 and $1.90 \mathrm{mg} / \mathrm{L}$ in Özen Spring. According to the TWPCR (2008) if biochemical oxygen demand is below $<4 \mathrm{mg} / \mathrm{L}$, the water is class-I; if it is $8 \mathrm{mg} / \mathrm{L}$, the water is class-II; if it is $20 \mathrm{mg} / \mathrm{L}$, the water is class-III and if biochemical oxygen demand is $>20 \mathrm{mg} / \mathrm{L}$, the water is class-IV. According to those limits, Özen Spring could be categorized as class-I. It is obvious that Özen Spring has a high water quality standard or class-I. Thus, it can be said that Özen Spring water can be used not only for drinking purpose by disinfecting it, but also for recreational purposes, rainbow trout culture, animal production and other purposes.

The turbidity has a mean of 4.58 NTU and shows ranges from 2.60 to 6.56 NTU in Özen Spring. The mean turbidity value in Özen Spirng not exceed the value proposed (5 NTU) by TWRHC (2005) 
water intended for human consumption. Also, the WHO (2004) state that for effective disinfection to take place, the turbidity levels in the water to be disinfected must be $<1.0$ nephelometric turbidity units (NTU).

The nitrate has a mean of $2.93 \mathrm{mg} / \mathrm{L}$ and shows ranges from 2.00 to $3.85 \mathrm{mg} / \mathrm{L}$ (Table 1 ). According to the TWPCR (2008) if nitrate is $<3 \mathrm{mg} / \mathrm{L}$, the water is class-I; if it is $10 \mathrm{mg} / \mathrm{L}$, the water is class-II; if it is $20 \mathrm{mg} / \mathrm{L}$, the water is class-III and if nitrate is $>20 \mathrm{mg} / \mathrm{L}$, the water is class-IV. According to those limits, Özen Spring could be categorized as class-I or high quality water. Thus, it can be said that Özen Spring water can be used not only for drinking purpose by disinfecting it, but also for recreational purposes, rainbow trout culture, animal production and other purposes. The nitrate values of all the water samples under the $10 \mathrm{mg} / \mathrm{L}$ permissible limit recommended by USEPA (2009) for nitrate. The nitrate levels are limited under the $50 \mathrm{mg} / \mathrm{L}$ recommended by ECDWD (1998), TWRHC (2005) and WHO (2011) for drinking water.

The nitrite has a mean of $0.03 \mathrm{mg} / \mathrm{L}$ and shows ranges from 0.00 to $0.05 \mathrm{mg} / \mathrm{L}$ in Özen Spring. According to the TWPCR (2008) if nitrite is $0.002 \mathrm{mg} / \mathrm{L}$, the water is class-I; if it is $0.01 \mathrm{mg} / \mathrm{L}$, the water is class-II; if it is $0.05 \mathrm{mg} / \mathrm{L}$, the water is class-III and if nitrite is $>0.05 \mathrm{mg} / \mathrm{L}$, the water is classIV. According to the mean nitrite level, Özen Spring could be categorized as class-III or polluted water. Thus, it can be said that Özen Spring water can be used for industrial water supply after a suitable treatment, except for industries that require quality water such as food, textiles. The mean nitrite level is limited under the $0.50 \mathrm{mg} / \mathrm{L}$ recommended by ECDWD (1998) and TWRHC (2005) for drinking water. The nitrite values of all the water samples under the $1 \mathrm{mg} / \mathrm{l}$ permissible limit recommended by USEPA (2009) for drinking water.

The orto-phosphate in water samples has a mean of $0.14 \mathrm{mg} / \mathrm{L}$ and shows ranges between 0.08 and $0.20 \mathrm{mg} / \mathrm{L}$ in Özen Spring. According to the TWPCR (2008) if orto-phosphate is $<0.05 \mathrm{mg} / \mathrm{L}$, the water is class-I; if it is $0.16 \mathrm{mg} / \mathrm{L}$, the water is class-II; if it is $0.65 \mathrm{mg} / \mathrm{L}$, the water is class-III and if orto-phosphate is $>0.65 \mathrm{mg} / \mathrm{L}$, the water is class-IV. According to those limits, Özen Spring could be categorized as class-II or slightly polluted water. Thus, it can be said that Özen Spring water can be used for drinking water supply with advanced or appropriate treatment, recreational purposes and aquaculture outside of rainbow trout. The orto-phosphate values obtained in the present study is normal for aquatic ecosystems within recommended range of $0.05-0.3 \mathrm{mg} / \mathrm{L}$ (Cirik and Cirik, 2008). According to Bulut et al., (2011) when phosphate concentration is over that $0.3 \mathrm{mg} / \mathrm{L}$, it means that eutrophication occurs in lake. According to those limits, the phosphate amounts detected in Özen Spring were at normal and low levels for aquatic ecosystems and eutrophication.

The sulfate has a mean of $3.35 \mathrm{mg} / \mathrm{L}$ and shows ranges from 1.19 to $5.50 \mathrm{mg} / \mathrm{L}$ (Table 1). According to the TWPCR (2008) if sulfate is below $200 \mathrm{mg} / \mathrm{L}$, the water is class-I; if it is $200 \mathrm{mg} / \mathrm{L}$, the water is class-II; if it is $400 \mathrm{mg} / \mathrm{L}$, the water is class-III and if sulfate is $>400 \mathrm{mg} / \mathrm{L}$, the water is class-IV. According to those limits, Özen Spring could be categorized as class-I. It is obvious that Özen Spring has a high water quality standard or I. class. Thus, it can be said that Özen Spring water can be used not only for drinking purpose by disinfecting it, but also for recreational purposes, rainbow trout culture, animal production and other purposes.

The concentration of chloride was between 7.01 and $9.60 \mathrm{mg} / \mathrm{L}$ in Özen Spring. According to the TWPCR (2008) if chloride is $25 \mathrm{mg} / \mathrm{L}$, the water is class-I; if it is $200 \mathrm{mg} / \mathrm{L}$, the water is class-II; if it is $400 \mathrm{mg} / \mathrm{L}$, the water is class-III and if chloride is $>400 \mathrm{mg} / \mathrm{L}$, the water is class-IV. According to those limits, Özen Spring could be categorized as class-I. It is obvious that Özen Spring has a high water quality standard or class-I. Thus, it can be said that Özen Spring water can be used not only for drinking purpose by disinfecting it, but also for recreational purposes, rainbow trout culture, animal production and other purposes. The chloride values are below the $250 \mathrm{mg} / \mathrm{L}$ recommended by ECDWD (1998), TWRHC (2005), USEPA (2009) and WHO (2011) for drinking water.

\section{Conclusions}

These results can serve as baseline data for water quality assessment of Özen Spring by physicochemical parameters and for comparisons with future studies. The values of each parameter were found to be within the safe limit values for safe drinking water set by ECDWD (1998), TWRHC (2005), USEPA (2009) and WHO (2011). According to the Turkish Water Pollution Control Regulation, TWPCR (2008) the Özen Spring has class-I or high quality water in terms of the conductivity, dissolved oxygen, oxygen saturation, $\mathrm{BOD}_{5}$, nitrate, sulfate and chloride parameters; 
class-II or slightly polluted water in terms of the orto-phosphate parameter and class-III or polluted water in terms of the nitrite parameter. According to the TWPCR (2008), all the investigated physicochemical parameters except for nitrite and orto-phosphate exhibited that all water samples are neutral and non-polluted, which can be used both for for drinking, recreational purposes, rainbow trout culture, animal production and other purposes. But the nitrite and orto-phosphate of the tested samples indicated that water from Özen Spring should be treated before to use mainly for drinking purposes. Periodic assessment of physicochemical analysis of the water of the studied Özen Spring should be carried out, in order to protect the aquatic ecosystems.

\section{REFERENCES}

[1] Bulut, S., Mert,R., Solak, K. \& Konuk, M. (2011). Some limonological properties of Selevir Dam Lake. Ekoloji, 20(80): 13-22.

[2] Cirik, S. and Ş. Cirik, 2008. Limnology. (in Turkish), Ege University, Fisheries Faculty Publication No: 21, İzmir, Turkey, pp: 1-166.

[3] Dirican, S., Çilek, S. 2014. Assessment of water quality of Gazibey Dam Lake, Sivas, Turkey for rainbow trout culture. Journal of Animal Science, 1 (1-2): 172-175.

[4] ECDWD, 1998. Drinking water directive 98/83/EC. Official Journal of the European Communities No: L330, 05 December 1998, 32-54.

[5] Egemen, Ö., 2011. Water Quality. (in Turkish), Ege University Fisheries Faculty Publication No: 14, İzmir, Turkey, pp: 1-150.

[6] TWPCR, 2008. Turkish water pollution control regulation. (in Turkish), Ministry of Environment and Forest, The Republic of Turkey Official Journal No: 26786, pp: 1-76.

[7] TWRHC, 2005. Turkish waters regulation for human consumption. (in Turkish), Official Journal of Turkey Republic, No: 25730, 17 February 2005, pp. 32.

[8] USEPA, 1980. Clean lakes program guidance manual. United States Environmental Protection Agency, Washington, D.C., Report No: EPA-440/5-81-003.

[9] USEPA, 2009. National primary drinking water regulations. EPA's safe drinking water hotline: (800)426-4791, United States Environmental Protection Agency, EPA 816-F-09-004, May 2009, pp. 1-6.

[10] WHO, 2004. Guidelines for drinking water quality. third edition, World Health Organization, Geneva, Switzerland, pp. 1-6.

[11] WHO, 2011. Guidelines for drinking water quality. fourth edition, World Health Organization, Geneva, Switzerland, pp. 1-541. 